\title{
repisälud
}

This is the peer reviewed version of the following article:

Menendez-Gutierrez, M. P., \& Ricote, M. (2017). The multi-faceted role of retinoid $X$ receptor in bone remodeling. Cellular and Molecular Life Sciences, 74(12), 2135-2149. doi:10.1007/s00018-017-2458-4

which has been published in final form at: https://doi.org/10.1007/s00018-017-2458-4 


\section{The multi-faceted role of Retinoid X Receptor in bone}

\section{2 remodeling}

3

4 María P. Menéndez-Gutiérrez, and Mercedes Ricote

5

6 Centro Nacional de Investigaciones Cardiovasculares Carlos III (CNIC),

7 Melchor Fernández Almagro, 3, 28029 - Madrid (Spain)

8 Tel: (+34) 914531200 ext. 3306

$9 \quad$ Fax: (+34) 914531265

10 Corresponding author: Ricote, M. (mricote@cnic.es)

11

12 Running title: RXRs in bone biology 


\section{Abstract (150-200 words)}

2 Retinoid $X$ receptors (RXRs) form a unique subclass within the nuclear receptor 3 (NR) superfamily of ligand-dependent transcription factors. RXRs are obligatory 4 partners for a number of other NRs, placing RXRs in a coordinating role at the 5 crossroads of multiple signaling pathways. In addition, RXRs can function as 6 self-sufficient homodimers. Recent advances have revealed RXRs as novel

7 regulators of osteoclastogenesis and bone remodeling. This review outlines the 8 versatility of $R X R$ action in the control of transcription of bone forming 9 osteoblasts and bone resorbing osteoclasts, both through heterodimerization with other NRs and through RXR homodimerization. RXR signaling is currently a major therapeutic target, and therefore knowledge of how RXR signaling

12 affects bone remodeling creates enormous potential for the translation of basic 13 research findings into successful clinical therapies to increase bone mass and 14 improve bone quality.

\section{Keywords}

17 Retinoid X Receptors, rexinoids, bone remodeling, osteoblasts, osteoclasts

Abbreviations

ALP: alkaline phosphatase

21 ATF4: activating transcription factor-4

ATRA: all-trans retinoic acid 
1 CalR: calcitonin receptor

2 CAR: constitutive androstane receptor

3 Col1a1: type I collagen a1

4 CRBP-1: cellular retinol-binding protein 1

5 CTSK: cathepsin K

6 DHA: docohexanoic acid

7 DR: direct repeat

8 ER: everted repeat

9 ERK: extracellular signal-regulated kinase

10 FXR: farnesoid $X$ receptor

11 IR: inverted repeat

12 LRP5: LDL receptor-related protein 5

13 LXR: Liver $X$ receptor

14 MAFB: v-maf musculoaponeurotic fibrosacroma oncogene family, protein B

15 M-CSF: macrophage colony-stimulating factor-1

16 NFATc1: nuclear factor of activated T cells, cytoplasmic 1

17 NR: nuclear receptor

18 Nurr1: nuclear receptor related 1

19 Nur77: nerve growth factor IB 
1 OC: osteocalcin

2 OP: osteopontin

3 OPG: osteoprotegerin

4 PPAR: peroxisome proliferator-activated receptor

$5 \quad$ PXR: pregnane $X$ receptor

6 RANKL: receptor activator of NF- $\kappa B$ ligand

7 RAR: retinoid acid receptor

8 Runx2: runt-related transcription factor-2

$9 \quad \mathrm{RXR}$ : retinoid $\mathrm{X}$ receptor

10 SRXRMs: selective retinoid $\mathrm{x}$ receptor modulators

11 TRAP: tartrate-resistant acid phosphatase

12 TR: thyroid hormone receptor

13 TZD: thiazolidinedione

14 VDR: vitamin D receptor

15 1,25(OH)2D: 1,25-dihidroxyvitamin D3

16 9-cRA: 9-cis retinoic acid 
3 Bone is a specialized connective tissue that also serves as an organ system in 4 higher vertebrates. Basic bone functions include protection of internal organs

Introduction and locomotion, and additionally the storage of minerals and lipids and the production of hematopoietic cells that nourish the body and play a vital role in protecting against infection. Recent studies have demonstrated that bone also produces hormones that control energy balance and mineral homeostasis, giving rise to the idea of the skeleton as a true endocrine organ [1]. Bone undergoes constant remodeling through a dynamic process of skeletal dissolution followed by bone formation. This cycle is maintained in a tight balance by highly regulated differentiation, activity, and apoptosis of two main cell types: bone-forming osteoblasts and bone resorbing osteoclasts [2-4]. These and other cells of the osteoblast family (osteocytes and lining cells) contribute to bone turnover by producing or responding to hormones, cytokines and growth factors implicated in bone development, remodeling, and repair [4, 5]. Differentiation and function of osteoblasts and osteoclasts is highly controlled at the transcriptional level by changes in the expression of numerous regulatory genes. Variations in the expression of these genes can result in altered bone homeostasis and the development of many bone diseases, such as osteoporosis [3].

Nuclear receptors (NRs) are transcription factors that are important effectors of signals regulating bone development and homeostasis. Many members of the NR superfamily respond to ligands known to affect bone homeostasis, including thyroxine and other hormones, vitamins $D$ and $A$, 
1 metabolites (e.g., dietary lipids), and drugs. To act as functional transcription

2 factors, receptors for all these molecules need to heterodimerize with retinoid $X$

3 receptors (RXRs). About a third of the 48 human NR superfamily members

4

5

6

7

8 serve as RXR heterodimerization partners, leading to RXRs being described as the central NRs [6]. RXRs were initially described as silent partners in these heterodimers, thought to have no transcriptional activity; however, RXRs are now known to actively contribute to the transcriptional activity of dimers in which they participate. In addition, RXRs control their own specific signaling pathways by acting as self-sufficient homodimers $[7,8]$. Because of the important roles of RXRs in diseases including cancer and metabolic, autoimmune, and neurodegenerative disorders, they have become major targets for drug discovery [9-11]. A number of potent synthetic RXR ligands (called rexinoids) have been described [12]. Rexinoids activate several heterodimers and also RXR homodimers, suggesting potential utility against multiple therapeutic targets. However, RXR-targeting drugs also have adverse effects in different organs. The design of effective treatment strategies therefore requires a thorough understanding of how RXRs regulate bone remodeling.

\section{The Retinoid X Receptors}

RXRs, much more than silent partners of other nuclear receptors

Mammals have three $R X R$ isotypes encoded by distinct genes: $R X R \alpha$ (NR2B1/RXRA), RXR $\beta$ (NR2B2/ RXRB), and RXR $\gamma$ (NR2B3/RXRG). The three RXR isotypes show tissue-specific expression, with partially overlapping 
1 functions [13]. RXRs are master regulators of gene expression, integrating and

2 modulating multiple functions through their ability to form obligate heterodimers

3 with many other NRs [13]. RXRs can also regulate gene expression as self-

4

5

6

7

sufficient homodimers or homotetramers, generating a so-far poorly explored complexity of RXR-dependent gene regulation. This versatility permits RXRs to exert pleiotropic transcriptional control over a wide range of biological processes, including cell differentiation, cell death, development, immune responses, and lipid and glucose metabolism.

RXR heterodimers are classified as permissive or non-permissive, depending on whether or not they can be activated by RXR ligands [14, 15]. Permissive heterodimers are formed with peroxisome proliferator-activated receptors (PPARs), liver $X$ receptors (LXRs), pregnane $X$ receptor (PXR), farnesoid $X$ receptor $(F X R)$, and the constitutive androstane receptor (CAR). These receptors are lipid-activated NRs with low affinity for their ligands. Also considered permissive are heterodimers formed by RXR and the orphan receptors Nurr1 and Nur77, because they activate transcription in response to RXR agonists [16]. Although Nur factors have no known endogenous ligands, several synthetic compounds act as Nur agonists [17-19] (Table 1). An important regulatory feature of permissive heterodimers is that binding by agonists for both partners could have a synergistic effect relative to that resulting from binding of a single receptor ligand [20]. Dual-ligand regulation of permissive heterodimers can result in robust transcriptional activity and thus achieve profound biological responses.

Non-permissive RXR heterodimers are formed with endocrine receptors with high affinity for their cognate ligands. These partners include retinoic acid 
1 receptors (RARs), vitamin D receptor (VDR), and thyroid receptors (TRs) [13].

2 Purely non-permissive heterodimers have intrinsic repressive activity in the

3 unliganded state, and are activated only by ligands specific for the partner NR,

4 with the RXR normally acting as an obligatory but silent partner. RXRs are

5 generally silent in VDR and TR heterodimers, although exceptions to this rule

6 have been described in specific conditions [13]. RAR/RXR heterodimers have

7 been termed conditionally non-permissive. These heterodimers can be further

8 activated by specific RXR ligands in addition to the RAR ligand, and in a few

9 cases RXR ligands have been observed to promote RAR/RXR function even

10 when an RAR ligand is absent [21].

$12 \mathrm{RXR}$, a promiscuous dimerization partner

The heterodimerization capacity of RXRs, together with the diversity of their ligands, suggests that RXRs can regulate a wide range of cellular pathways. This is possible due to the complex and highly regulated mechanism by which

17 RXRs regulate the transcriptional activity of multiple genes. Although RXRs can establish heterodimers with other NRs spontaneously [22], dimerization is normally ligand-dependent. RXRs form transcriptionally inactive unliganded homotetramers that upon ligand binding dissociate to allow the formation of

21 homo- and heterodimers [23]. Thus, one level of regulation of RXR activity depends on the local availability of ligands for RXRs and their heterodimeric partners. Another level of regulation relies on the binding of RXRs and their heterodimer partners to consensus DNA motifs in target genes [13]. These consensus motifs consist of two copies of the hexamer AGGTCA, or derivatives 
1 of this, arranged as tandem repeats. The specificity of each of these NR/DNA

2 interactions is encoded by the orientation of the repeats (direct- (DR), inverted-

3 (IR), or everted-repeats (ER)), as well as the number of nucleotides separating

4 the two half-sites of the repeat (normally 1-5 nucleotides). Many homodimers

5 and heterodimers compete for the same response elements (Table 1). For

6 instance, PPAR $\alpha$-independent activation of DR1 response elements has been

7 described, suggesting that $\mathrm{RXR} \alpha$ homodimers can bind on PPAR response

8 elements and provides a molecular basis for the activation of some PPAR $\alpha$

9 target genes by rexinoids in vivo [24]. Which genes are expressed in a specific

10 tissue may thus be determined by the local abundance of RXRs and their

11 partners. Promoter-bound RXRs moreover recruit various co-factors, including

12 histone modifying enzymes and chromatin remodeling complexes [13]. RXRs generally bind corepressors that suppress their transcriptional activity in the absence of agonists [13]. The presence of agonists shifts the equilibrium from

RXR-corepressor complexes to RXR-co-activator complexes, stimulating transcriptional activity. The dynamics and recruitment of co-factor complexes thus constitute another level of RXR regulation.

Therapeutic potential of RXR modulation

RXRs were first described in 1990 by Mangelsdorf et al. as NRs able to respond to vitamin A derivatives, with a remarkable ligand specificity for 9-cis retinoic acid (9-cisRA) [25, 26]. However, the identity of the physiological RXR ligands is still debated, and there is particular uncertainty about the status of 9-cisRA as an endogenous RXR agonist because many groups have been unable to detect 
1 endogenous 9-cisRA in vivo $[13,27,28]$. More recently, other vitamin A

2 metabolites, such as all-trans-retinaldehyde [29], b-apo-14'-carotenal [30],

3 dihydroretinoids [31], and 9-cis-13,14-dihydroretinoic acid [32], have been

4 demonstrated to act as endogenous RXR ligands in several tissues. Even all-

5 trans retinoic acid (ATRA), which was always considered an RAR-specific

6 ligand, has been suggested to directly bind and activate RXRs [33]. In addition,

7 RXR may function as a fatty acid receptor in vivo, since some flexible

8 unsaturated fatty acids, either endogenously produced or derived from the diet,

9 were recently shown to act as natural RXR ligands. These compounds include

10 methoprenic acid, phytanic acid, docosahexaenoic acid (DHA),

11 docosatetraenoic acid, and arachidonic acid (reviewed in [13, 28]). These

12 findings suggest that RXRs can directly act as intracellular sensors that regulate cell and tissue homeostasis.

Interest in the pharmacological potential of RXR ligands arose from their strong apoptotic effect in vitro [34]. The subsequent development of several RXR-specific synthetic ligands, known as rexinoids, has revealed their potential as chemotherapeutic agents and metabolic regulators. The rexinoid bexarotene (Targretin $®$ ), a pan-RXR agonist, is already used to treat refractory or persistent cutaneous T-cell lymphoma cancer [35], and others are being tested in preclinical settings to treat insulin resistance [36]. The anticarcinogenic and metabolic effects of rexinoids are proposed to derive from the ability of RXRs to form homodimers and homotetramers [24, 37]. However, the clinical use of rexinoids is limited by secondary effects resulting from the activation of mainly $L X R / R X R$ and TR/RXR heterodimers, which provokes a rise in triglyceride levels, suppression of the thyroid hormone axis, and the induction of 
1 hepatomegaly [38]. There is therefore much interest in the design of selective

2 RXR modulators (SRXRMs) that target RXR homodimers or specific RXR

3 heterodimers [11].

\section{$5 \quad$ Bone turnover and remodeling}

6

7 Bone density increases rapidly during adolescence, peaking approximately 10

8 years after the completion of skeletal growth [39]. In the adult skeleton, bone mass is homeostatically maintained by continuous replacement of old tissue with new bone tissue, which is the basis of the dynamic process of bone turnover and remodeling. An increase in bone resorption unbalanced by bone formation leads to bone loss [3]. Bone loss is a natural consequence of aging, but can also be accelerated by numerous conditions, leading to skeletal damage at a relatively young age. These conditions include postmenopausal osteoporosis, autoimmune diseases, periodontal infection, hyperparathyroidism resulting from cancer or impaired calcium absorption, infection with human immunodeficiency virus, and type 1 diabetes [40,41]. Bone loss is also an adverse secondary effect of certain pharmacological drugs, such as PPAR $\gamma$ specific agonists thiazolidinediones (TZDs), which increase fracture risk and are a cause of secondary osteoporosis [42].

The main protagonists in the complex process of bone remodeling are bone-resorbing osteoclasts and bone-forming osteoblasts [3]. These two cell types are regulated by a multitude of systemic and local factors, including cytokines, growth factors, hormones, the immune system, and mechanical load. Although osteoblast and osteoclast activities are closely integrated, these cell 
1 types originate from different lineages and have opposing functions within the

2 bone remodeling cascade.

4 Bone resorption and osteoclasts

6 Bone resorption is initiated by the proliferation and fusion of osteoclast 7 precursors, monocyte/macrophage hematopoietic cells that give rise to 8 multinucleated specialized osteoclasts. Pre-osteoblastic stromal cells produce 9 two factors that together are necessary and sufficient for bone resorption: receptor activator of NF-KB ligand (RANKL) and macrophage colony-stimulating factor-1 (M-CSF) [43]. Activation of M-CSF receptor in osteoclast progenitors triggers precursor proliferation, whereas RANK activation promotes osteoclast differentiation. Osteoclast differentiation and cell fusion are promoted by the dynamic expression of pro-osteoclastogenic transcription factors, such as c-fos and NFATc1 (nuclear factor of activated T cells, cytoplasmic 1). These factors up-regulate expression of genes encoding osteoclast function molecules, 17 including cathepsin K (CTSK), tartrate-resistant acid phosphatase (TRAP), calcitonin receptor (CaIR), dendritic cell-specific transmembrane protein, and b3-integrin7 [2]. Thereafter, the mature osteoclasts form polarized actin filaments and migrate to the bone to form a sealing zone between osteoclasts and the bone matrix. Osteoclasts then secrete proteolytic enzymes and acids,

22 forming a low pH local environment and degrading organic and inorganic bone components. After bone matrix degradation, the osteoclasts detach from the site and migrate to a new resorption site. Osteoblasts then move into the area to replace the resorbed bone. 
2 Bone formation and osteoblasts

3

4 Osteoblasts are bone-forming cells derived from mesenchymal stem cells [2].

5 Like osteoclastogenesis, osteoblast differentiation is regulated by several

6 transcription factors, in this case including runt-related transcription factor-2

7 (Runx2), osterix (Osx), and activating transcription factor-4 (ATF4). Osteoblasts

8 secrete bone matrix proteins such as alkaline phosphatase (ALP), type I

9 collagen a1 (Col1a1), and other non-collagen proteins such as osteocalcin (OC)

10 and osteopontin (OP). The osteoblast lineage regulates osteoclastogenesis in

11 the bone microenvironment through the release of RANKL and M-CSF. A

12 further level of regulation is provided by the osteoblast production of the RANKL

13 decoy receptor osteoprotegerin (OPG) [44]. OPG binds to RANKL, blocking its

14 interaction with RANK on osteoclast precursors and thus inhibiting osteoclast

15 activity. Once osteoblasts have formed the bone they become quiescent bone-

16 lining cells on the newly formed bone surface. In the adult skeleton, bone-lining

17 cells cover most bone surfaces not undergoing formation or resorption.

\section{Role of RXRs in bone remodeling}

21 Evidence accumulated of several decades points to a role for RXR 22 heterodimers in skeletal homeostasis (reviewed in [45-47]). However, these studies have generally focused on the RXR-partner, relegating RXRs to the status of silent NR in these heterodimers. Our recent study combining genetic loss-of-function and pharmacological gain-of-function strategies revealed a 
1 direct anti-osteoclastogenic function of RXRs in mice [8]. Additionally, RXR $\alpha$

2 methylation in umbilical cord DNA from children aged 4 years was recently

3 linked to lower bone mineral content, identifying $\mathrm{RXR} \alpha$ as a novel biomarker in

4 early life for adverse bone outcomes [48]. In this review we discuss the

5 importance of RXRs in bone remodeling, beyond their subordinate role as

6 heterodimer partners of other NRs.

7

8 Osteoblasts and osteoclasts express RXRs and RXR-partner NRs

9

The $R X R \alpha, R X R \beta$, and $R X R \gamma$ isotypes are involved in a plethora of tissue- and

11 isotype-specific biological responses [13], and all cells in the body express at

12 least one RXR isotype [49]. Of the 49 NRs found in rodents, around one third

13 has been shown to form heterodimers with RXRs $[13,50]$. Many of these NRs are expressed in the osteoblast and osteoclast lineages, and a number of them can modulate their differentiation and activation, as we discuss below.

Expression studies in calvarial osteoblast primary cultures and mesenchymal and osteoblastic cell lines show that the three $R X R$ isotypes and their heterodimer partners are widely expressed in the osteoblast lineage [51-56] (Table 1). Osteoclast progenitors, which are bone marrow myeloid cells, express $R X R \alpha$ and $R X R \beta$, but not $R X R \gamma[8,57]$. Several $R X R$ heterodimer partners, including PPARs, RARs, and LXRs, are expressed at several stages of osteoclast differentiation, and are found in bone marrow derived macrophages, osteoclast cell lines, and cultured osteoclasts [45, 52, 57-63] (Table 1). 
1 Mouse models of RXR and RXR-partner function in the skeleton

2

3 The generation of mice carrying RXR gene deletions or mutations has been a

4 valuable tool for investigating the impact of RXRs on biological functions.

5 Animals with systemic deletions have been generated for each of the three RXR

6 isotypes. However, these deletions result in lethality, or cause systemic

7 abnormalities that mask cell- and tissue-specific effects. For examples,

8 ubiquitous inactivation of $\mathrm{RXR} \alpha$ is embryonically lethal at mid-gestation due to

9 hypoplastic development of the ventricular myocardium [64]. RXR $\beta$ knockout

10 mice show reduced spermatid formation, whereas $\mathrm{RXR} \gamma$ knockout induces

11 metabolic defects $[65,66]$; however, these mice show no evident bone

12 alterations (Table 2).

The physiological functions of RXRs in specific tissues, including the bone, have been investigated in cell-type-specific RXR gene knockout mice (reviewed in [67]). The MxCre-mediated loxP recombination system was used to specifically delete RXR isotypes expressed in murine osteoclast progenitors. The lack of hematologic effects in mice lacking $R X R \alpha$ suggested that $R X R \beta$ might compensate for the loss of $R X R \alpha$ in bone marrow cells [68]. To address the possibility of compensation, mice were generated with double deletion of $R X R \alpha$ and $R X R \beta$. These mice had complete deletion of the $R X R \alpha$ and $\mathrm{RXR} \beta$ genes in all hematopoietic organs, including whole bone marrow, undifferentiated lineage marker-negative and mature lineage marker-positive cells, and osteoclasts [8]. Our examination of this mouse model revealed an important role for RXR homodimers in bone homeostasis and bone remodeling through the control of differentiating osteoclasts [8] (Table 2). Loss of RXR 
1 function in osteoclast progenitors resulted in formation of non-resorbing

2 osteoclasts. Although these osteoclasts were larger than those from wild type

3 animals, they had defects in bone resorption due to their deficient expression of

4 activity genes and failure to form cytoskeletal structures necessary for

5 resorption of the bone matrix. This resulted in increased bone mass in male

6 mice and protection from bone loss in an experimental model of

7 postmenopausal osteoporosis. The increase in bone mass was due to lack of

8 expression in osteoclast progenitors of the transcription factor MAFB ( $\mathrm{v}$-maf

9 musculoaponeurotic fibrosarcoma oncogene family, protein B), which was

10 shown to be necessary for their proper M-CSF-dependent proliferation and

11 further differentiation into functional osteoclasts. These studies demonstrated

12 that in the absence of exogenous RXR ligand, RXR homodimers directly target and bind the Mafb promoter. These results suggest that RXR endogenous ligands might be produced during osteoclastogenesis. Supporting this idea, the fatty acid RXR ligands arachidonic acid and DHA have been found to play a role in osteoclastogenesis $[69,70]$. However, the physiological role of RXR

17 homodimers will remain an open question until the endogenous RXR ligands in the bone environment are revealed.

The promiscuity of RXRs, arising from their capacity to form heterodimers with many other NRs, makes it difficult to define the functions of RXR homodimers because in most cases the phenotypes observed in RXR mutant mice can be linked to alterations in pathways regulated by one or many RXR heterodimer partners. To unambiguously determine the specific dimer responsible for the bone phenotype of mice lacking RXRs, it is necessary to compare this phenotype with those presented by mice lacking RXR heterodimer 
1 partners. Systemic or cell-specific deficiency models for several RXR

2 heterodimeric partners have revealed the importance of many of these NRs in

3 the control of bone remodeling (Table 2). General deletion of VDR and TR, long

4 established as regulators of bone and mineral homeostasis, has profound

5 skeletal effects (for detailed reviews see [71-73]). VDR knockout mice present a

6 general phenotype that mimics human vitamin D-dependent hereditary rickets

7 type II, whose main clinical manifestations are low bone mineral density, rachitic

8 malformation, growth retardation and short stature, hypocalcemia,

9 hypophosphatemia, and hyperparathyroidism. Studies in VDR knockout mice

10 reveal that the main role of VDR is to maintain serum calcium and phosphate

11 homeostasis. VDR signaling additionally plays a direct role in osteoblast

12 differentiation and an osteoblast-mediated role in osteoclastogenesis. The action of thyroid hormone on bone is mediated principally by $\operatorname{TR} \alpha$, which is expressed in the skeleton at much higher levels than TR $\beta$. Mutation of TR $\beta$ disrupts the hypothalamic-pituitary axis, leading to systemic hyperthyroidism and overstimulation of intact TR $\alpha$ in bone. Thus, deletion or mutation of each of these receptors has opposite effects. TR $\alpha$ mutant mice have elevated bone mass as a result of reduced osteoclast activity resulting from the impaired thyroid hormone action in bone. In contrast, $\operatorname{TR} \beta$ mutant mice have osteoporosis as a result of accelerated bone resorption due to the effects of systemic hyperthyroidism.

Studies reported in the last five years provide new insight into the role in bone remodeling of other RXR heterodimeric partners. General deletion of PPAR $\beta / \delta$ [74], RAR $\gamma$ [75], PXR [62], FXR [61], or Nur77 [63] in mice provokes osteopenia. In all these models, the systemic lack of the RXR heterodimeric 
1 partner increases osteoclastogenesis, due to the loss of either a direct or a

2 paracrine effect of the NR on osteoclastic cells. Mice conditionally lacking

$3 \mathrm{PPAR} \beta / \delta$ in all tissues except the placenta (Ppard ${ }^{\text {Sox2-cKO }}$ ) have an above-

4 normal osteoclast count and osteopenia due to decreased Wnt signaling in

5 bone-lining osteoblasts [74]. Wnt/ $\beta$-catenin signaling is required to direct

6 mesenchymal progenitor cells toward the osteoblast lineage, and its inactivation

7 imbalances bone formation and resorption due to a decline in the level of

8 osteoblast-secreted OPG [76]. PPAR $\beta / \delta$-deficient mice have an elevated

9 RANKL-to-OPG ratio, thereby influencing the rate of osteoclastogenesis.

10 Among RAR deletion mutants, only RAR $\gamma$ knockouts show increased

11 osteoclastogenesis and osteopenia [75]. The authors of this study suggested

12 that the increased bone resorption was in part due to an increase in osteoclast

13 size but not in osteoclast numbers. Notably, both RAR $\gamma$ and RXR-double

14 knockout mice have abnormally large osteoclasts [8, 75]. However, whereas in

15 the RAR $\gamma$ knockout model this results in apparently elevated lytic activity, RXR-

16 double knockout mice have bone resorption defects. Increases in osteoclast

17 size in vivo have been linked either to reduced osteoclast resorptive activity [77]

18 or to increased osteoclast activity $[78,79]$. The authors did not further explore

19 the mechanism underlying this RAR-mediated osteoclast phenotype, but

20 speculated that it must involve M-CSF-mediated increased osteoclast

21 progenitor fusion. In the case of RXR-deficient osteoclasts, our work excluded

22 changes in the expression of cell fusion and adhesion molecules as the cause

23 of the giant and resorption-deficient osteoclast phenotype [8]. Rather, we found

24 that RXR dependent expression of MAFB was involved in M-CSF-dependent

25 proliferation of osteoclast progenitors and that this affected osteoclastogenesis. 
1 The reduced bone mass in female mice lacking PXR [62] and male mice lacking

2 FXR [61] was proposed to be due both to decreased bone formation and

3 increased bone resorption. Histomorphometrical differences observed in the

4 trabecular bones of female $\mathrm{Pxr}^{-1-}$ mice accounted for the osteopenic phenotype

5 of these mice, but the underlying mechanism remains unexplored [62]. Calvarial

6 cells from $\mathrm{Fxr}^{-1-}$ mice show reduced expression of the osteoblast-specific

7 transcription factors Runx2 and Osx and osteoblast marker genes, including

8 Col1a1, ALP, and OC. The increased osteoclast activity of $\mathrm{Fxr}^{-1-}$ mice was

9 shown to be mediated both by osteoblasts and by osteoclasts. On the one 10 hand, augmented expression of RANKL by FXR-deficient osteoblasts increased

11 RANKL/OPG ratio, which could account for the increased bone resorption status. On the other hand, the lack of FXR in osteoclast precursors resulted in increased expression of the NFATc1 protein. NFATc1 is the key transcriptional factor for osteoclastogenesis [80], and its induction could therefore account for the elevated bone resorption in $\mathrm{Fxr}^{-1-}$ mice. Similarly, increased expression of NFATc1 is involved in the osteopenic phenotype of general Nur77 knockout 
1 knockout mice. Among the mouse models of deficiency for RXR heterodimer

2 partners, the only ones to show increased bone mass are systemic or

3 osteoclast-specific PPAR $\gamma$ knockouts [81, 82], systemic LXR $\alpha$ knockouts [60],

4 systemic CAR knockouts [52], and chondrocyte-specific VDR knockouts [83]

5 (Table 2). However, the mechanisms underlying this phenotype are different

6 from that described in RXR-double knockout mice. For example, mice with

7 general deletion of PPAR $\gamma\left(\operatorname{Pparg}^{+-}\right)$have high bone mass due to increased

8 osteoblast number and bone formation rather than bone resorption [81]. The

9 authors observed that PPAR $\gamma$ insufficiency favored differentiation of osteoblasts over adipocytes from their shared mesenchymal progenitor, a finding consistent with the role of PPAR $\gamma$ in adipogenesis [84]. The mechanism for this action remained unclear, since the authors observed an upregulation of key molecules for osteoblast differentiation (Runx2, Osx, and LRP5, the LDL receptor-related protein 5), but could not demonstrate direct binding of PPAR $\gamma$ to the promoter of these genes. More recently, PPAR $\gamma$ was revealed to play a role not only in osteoblastogenesis, but also in osteoclastogenesis [82]. Loss of PPAR $\gamma$ function in mouse hematopoietic lineages (Tie2Cre/Pparg ${ }^{\mathrm{fl} / f l}$ ) causes osteoclast defects and impaired bone resorption. The lack of osteoclast bone resorbing activity in these mice is due to complete blockade of osteoclast differentiation and reduction of c-fos expression [82]. Osteoclasts from mice with general deletion of LXR $\alpha\left(\mathrm{Lxra}^{-/-}\right)$are unable to effectively resorb bone in the cortical compartment [60]. The authors speculated that $L X R \alpha$ might regulate late stages of osteoclast function rather than their differentiation from progenitor cells; however, the underlying mechanism was not defined. In male mice with systemic deletion of CAR $\left(\mathrm{Car}^{-1-}\right)$, the increased bone mass observed was 
1 attributed to decreased hepatic expression of Cyp2b and a consequent

2 reduction in testosterone metabolism [52]. Positive correlations between

3 testosterone concentration and bone mass had been reported previously in

4 animals and humans [85]. The mechanism driving the testosterone effect in

5 bone is increased osteoprotegerin mRNA expression in mouse osteoblast cells

6 [86]. Finally, the specific absence of VDR in chondrocytes (Col2Cre ${ }^{+/-V D R}{ }^{\mathrm{fl} / f \mathrm{l}}$ )

7 impairs osteoclastogenesis during early postnatal life [83]. Although the authors

8 aimed to elucidate the function of VDR during growth-plate development and

9 endochondral bone formation, growth plate morphology was normal in these

10 mice. Unexpectedly, the authors demonstrated a VDR-mediated paracrine loop

11 between chondrocytes, osteoblasts/osteocytes, and osteoclasts. The decrease

12 in osteoclastogenesis in these mice is secondary to a decrease in chondrocyte

13 RANKL production. These mice also have elevated levels of circulating

14 phosphate and the VDR ligand 1,25-dihydroxyvitamin D3 (1,25(OH)2D) before weaning. This was thought to be due to decreased osteoblast expression of the phosphaturic hormone fibroblast growth factor 23 (FGF23) [83], which plays a direct role in skeletal remodeling through the control of osteoclastogenesis [87]. These studies together indicate that RXRs play pleiotropic functions as heterodimeric partners of other NRs with important roles in bone remodeling. Remarkably, because none of the RXR heterodimer partner-knockout mice recapitulate the mechanism leading to increased bone mass in $R X R$-deficient mice, these studies also support a previously unrecognized proosteoclastogenic function of RXR homodimers in physiological conditions.

Protective effect of pharmacological RXR activation on bone loss 
The role of retinoids in bone biology has been studied extensively (for a detailed review see [88]). Numerous clinical studies have assessed the link between vitamin A intake and fracture risk; however, it remains unclear whether vitamin $A$ is deleterious or protective to bone. The transcriptional effects of retinoid signaling are mediated through RAR/RXR heterodimers. RARs can be activated by all-trans retinoic acid (ATRA) and by 9-cisRA, whereas RXRs are activated only by 9-cisRA. Additionally, 9-cisRA induces RXR homodimer formation in vitro, suggesting the existence of a retinoid response pathway distinct from that activated by the heterodimer RAR/RXR [89]. Here we summarize the effects on bone remodeling of 9-cisRA and rexinoids, as well as several RXR permissive heterodimeric partner agonists (Table 3). However, it is important to note that in specific conditions even the non-permissive heterodimers might be directly activated by RXR agonists, depending on factors such as tissue specificity, the cellular environment, and the ability of various RXR ligands to recruit coactivator or corepressor complexes [13].

Our recent study demonstrated that in vitro RXR activation of bone marrow osteoclast progenitors with the rexinoid LG100268 inhibits osteoclastogenesis [8]. This effect was unexpected, given the antiosteoclastogenic effect of RXR deficiency under baseline conditions. Treatment with LG100268 upregulates MAFB expression during in vitro osteoclast differentiation, blocking RANKL signaling and consequently the formation of mature active osteoclasts. This result is in agreement with a previously described anti-osteoclastogenic role of MAFB, which when overexpressed in osteoclast progenitors attenuates the expression of NFATc1 during RANKL- 
1 mediated osteoclastogenesis [90]. Our studies demonstrated that in vivo

2 pharmacological activation of RXRs with bexarotene significantly diminished

3 osteoclast activation and bone resorption in ovariectomized mice, but had no

4 significant effect on steady-state bone turnover. The effect of bexarotene in

5 steady-state conditions was recently tested in male Wistar rats [91]. Although

6 the authors reported variations in the levels of OC and plasma TRAP, as well as

7 in bone parameters, these changes were mild [91]. These results suggested

8 that pharmacological RXR activation has no major effect in physiological conditions, but might be protective against bone loss after the menopause

Whether RXR activation affects osteoblast differentiation and activation is debated. Recent studies report that 9-cisRA induces osteogenic differentiation of mesenchymal progenitor cells [92] and promotes osteogenic markers in mesenchymal progenitor cells [92] and human osteosarcoma cell lines [93]. However, long-term treatment with 9-cisRA inhibits differentiation of primary calvarial osteoblast cultures [94]. Decreases in ALP activity, mineralization, and expression of osteoblast-related genes are achieved in primary mouse mesenchymal stem cells upon RXR activation with bexarotene, LG100268, and the organotin contaminant tributyltin, which is also a known PPAR $\gamma$ agonist [95]. However, we found no changes in osteoblast number or activity in mice treated with bexarotene [8]. We concluded that $\mathrm{RXR}$ activation in mice provokes defects in osteoclastogenesis as a consequence of MAFB regulation, but other RXR-modulated signaling pathways could be involved in this effect. For instance, RXR agonists induce proteasome-mediated $\beta$-catenin degradation [96]. RXR-mediated $\beta$-catenin degradation is inhibited by cellular retinol-binding protein 1 (CRBP-1), a factor implicated in vitamin A metabolism and intracellular 
1 retinoid transport [97]. Wnt/ $\beta$-catenin signaling influences progenitor cell

2 differentiation toward osteoblasts or osteoclasts [76], and it is therefore possible

3 that modifications of $\mathrm{Wnt} / \beta$-catenin signaling could account for the skeletal

4 phenotype of bexarotene-treated mice. In addition, agonists of diverse RXR

5 permissive heterodimers modulate other genes regulating osteoclast and

6 osteoblast differentiation and activity, as discussed below.

7

We recently reported that rexinoids inhibit osteoclastogenesis via indirect regulation of Mafb expression, through LXR/RXR-induced expression of the master lipid homeostasis regulator SREBP-1c (sterol regulatory element binding protein-1c) $[8,98]$. This is supported by an earlier report showing that LXRspecific ligand GW3965 induces Mafb expression and blocks in vitro osteoclastogenesis of human and murine osteoclast progenitors [99]. The authors concluded that the effect of GW3965 on osteoclastogenesis was NFATc1/p38/MITF-dependent and c-Fos or RANK-independent. Moreover, abolition of these effects in $L X R \beta^{-/-}$osteoclast precursors suggested that the LXR-specific ligand acts via an LXRß-dependent mechanism [99]. Also consistent with the bexarotene data [8], treatment of ovariectomized mice with the LXR-specific agonist T0901317 provides protection from estrogen-depletioninduced bone loss [100]. The authors of this study concluded that the effects of LXR on osteoclastogenesis are osteoblast-mediated: in osteoblast/osteoclast co-cultures, LXR activation reduced the RANKL/OPG ratio, but when osteoblasts were absent no changes were observed in the number of in vitro differentiated osteoclasts, despite clear reductions in osteoclast size and activity [100]. However, our work shows that T0901317 blocks in vitro differentiation of osteoblast-free wild type osteoclast cultures but not of their RXR-deficient or 
1 LXR-deficient counterparts [8], demonstrating an osteoblast-independent role of

2 LXR activation in osteoclastogenesis. Another study claimed that the effects of

3 LXR activation on murine osteoblasts depend on the duration of ligand exposure [101]. In this study, short T0901317 exposure decreased OC levels in primary murine osteoblasts and in male mice. However, long-term oral administration of T0901317 or GW3965 did not alter trabecular and cortical bone structure or bone turnover in female [101]. The gender effect in this study suggests that LXR activation effects are not exclusively dependent on treatment duration. Indeed, our work with RXR double-knockout mice demonstrated that the physiological role of RXRs in osteoclastogenesis is gender-dependent, affecting the bone phenotype of males but not females [8]. These data suggested that osteoclast function is influenced in vivo by estrogenic contributions to the transcriptional modulation of RXRs and probably LXRs.

Agonists for the three PPAR isotypes, $\alpha, \delta / \beta$ and $\gamma$, have diverse effects on bone remodeling. PPAR $\alpha$ activation with bezafibrate has anabolic effects on bone in vitro, stimulating osteoblast differentiation (shown by increased ALP activity, collagen production, and calcification) [102], and inhibiting the formation of human multinucleated osteoclasts [103]. The effect of PPAR $\beta / \delta$ activation in bone is more confusing. Activation of PPAR $\beta / \delta$ with GW501516 induces Wntdependent expression of osteoblast marker genes in osteoblasts and mesenchymal cells and has an osteoblast-mediated inhibitory effect on osteoclastogenesis [74]. However, two independent reports showed that PPAR $\delta / \beta$ activation can induce bone resorption. In one report, carbaprostacyclin-mediated PPAR $\delta / \beta$ activation upregulated CTSK and TRAP expression and potently induced the bone-resorbing activity of isolated mature 
1 rabbit osteoclasts [104]. Accordingly, in cultured human osteoclasts derived

2 from peripheral blood mononuclear cells, PPAR $/ \beta$ activation with L165041

3 stimulated the resorptive activity of mature osteoclasts [103]. The role of PPAR $\gamma$

4 activation in bone biology has been extensively studied due to its detrimental

5 effects on bone anabolism in mice and humans (for reviews see $[105,106]$ ).

6 Recent trials report that long-term treatment of insulin resistance with the

7 synthetic PPAR $\gamma$ agonist rosiglitazone increases fracture rates among diabetes

8 patients [107]. PPAR $\gamma$ activation both suppresses osteoblastogenesis and

9 activates osteoclastogenesis, thereby decreasing bone mass as a net effect.

10 Agonists of FXR increase bone formation while decreasing bone 11 resorption. In vitro FXR activation with bile acids or synthetic FXR agonists enhances osteoblast differentiation through the transactivation of Runx2 [56] and enhanced signaling via extracellular signal-regulated kinase (ERK) and $\beta$ catenin [61]. As a consequence, FXR agonists stimulate the expression of osteoblast marker genes such as bone sialoprotein, OC, OP, and ALP [56]. FXR agonists also suppress RANKL-induced osteoclast differentiation from bone marrow macrophages and inhibit the expression of $c$-fos and NFATc1; however, the molecular mechanism driving these effects was not dissected [61]. Accordingly, a farnesol-enriched diet marginally protects against ovariectomyinduced bone loss and enhances bone mass gain in growing mice [61]. Finally, bone formation is potentiated by PXR activation with the anti-osteoporotic agent menaquinone-4 (Vitamin K2) [108], which induces the expression of key osteoblastic marker genes like ALP, OPG, OC, and OP [53] and extracellular matrix-related genes involved in collagen assembly [109]. 
RXR activation by rexinoids thus blocks osteoclast differentiation and

2 protects against bone loss in postmenopausal conditions. This protective effect

3 is driven by the activation of $L X R / R X R$ and probably PPAR $\alpha / R X R$ and

$4 \quad F X R / R X R$ in cells of the osteoclast lineage. Bone anabolic effects might also be

5 achieved by the activation of PPAR $\alpha / R X R, P P A R \beta / \delta / R X R, F X R / R X R$, or

$6 \quad P X R / R X R$ in osteoblastic cells.

7

\section{Concluding remarks}

9 homodimers.

Despite the growing body of literature on the roles of NRs in bone biology, few studies have examined the key role of RXRs, which were historically studied as subordinate partners of other NRs. However, we and others have demonstrated that RXRs can be directly activated by specific ligands and modulate multiple signaling pathways in vivo both as heterodimers with other NRs and as

The studies summarized in this review indicate that RXRs can modulate osteoclast and osteoblast formation and function at several levels of cell differentiation and activation (Figure 1). Remarkably, under physiological conditions RXRs control osteoclast progenitor proliferation and osteoclast activation independently of RXR heterodimeric partners with known roles in bone physiology. This finding supports an in vivo role for RXR homodimers, indicating that they can function as biologically relevant transcription units. Pharmacological RXR activation blocks osteoclast differentiation and protects female mice from estrogen-depletion-induced bone loss. Notably, the effects of RXR activation on bone remodeling are independent of PPAR $\gamma$. This finding is 
1 important because PPAR $\gamma$ ligands have negative effects on bone anabolism in

2 mice and humans, challenging their therapeutic benefits as insulin sensitizers.

The studies reviewed here highlight the potential utility of RXR ligands for

4 the treatment of low bone mass disorders. However, medical use of currently

5 available pan-RXR modulators is limited by the pleiotropic effects of $R X R$

6 activation. This issue could be solved by the design of selective RXR

7 modulators (SRXRMs) with cell-specific and dimer-specific effects. For

8 instance, protection against bone loss might be achieved without undesirable

9 secondary effects through the use of specific RXR homodimer antagonists in

10 bone marrow progenitors or of specific LXR/RXR heterodimer agonists in

11 differentiating osteoclasts. Advances in SRXRM development and the bonespecific delivery of these agents have the potential to overcome the current limitations to $\mathrm{RXR}$ targeting.

\section{Acknowledgements}




\section{References}

1. Digirolamo DJ, Clemens TL, Kousteni S (2012) The skeleton as an endocrine organ. Nat Rev Rheumatol 8(11):674-683.

2. Teitelbaum SL, Ross FP (2003) Genetic regulation of osteoclast development and function. Nature reviews. Genetics 4(8):638-49. doi:10.1038/nrg1122

3. Feng X, Mcdonald JM (2011) Disorders of bone remodeling. Annual review of pathology 6:121-45. doi:10.1146/annurev-pathol-011110130203

4. Kular J, Tickner J, Chim SM, Xu J (2012) An overview of the regulation of bone remodelling at the cellular level. Clinical biochemistry 45(12):86373. doi:10.1016/j.clinbiochem.2012.03.021

5. Bellido T (2014) Osteocyte-driven bone remodeling. Calcified tissue international 94(1):25-34. doi:10.1007/s00223-013-9774-y

6. Nahoum V, Perez E, Germain P, Rodriguez-Barrios F, Manzo F, Kammerer S, Lemaire G, Hirsch O, Royer CA, Gronemeyer H, De Lera AR, Bourguet W (2007) Modulators of the structural dynamics of the retinoid $X$ receptor to reveal receptor function. Proceedings of the National Academy of Sciences of the United States of America 104(44):17323-8. doi:10.1073/pnas.0705356104

7. Nunez V, Alameda D, Rico D, Mota R, Gonzalo P, Cedenilla M, Fischer T, Bosca L, Glass CK, Arroyo AG, Ricote M (2010) Retinoid X receptor alpha controls innate inflammatory responses through the up-regulation 
of chemokine expression. Proc Natl Acad Sci U S A 107(23):10626-31. doi:10.1073/pnas.0913545107

8. Menendez-Gutierrez MP, Roszer T, Fuentes L, Nunez V, Escolano A, Redondo JM, De Clerck N, Metzger D, Valledor AF, Ricote M (2015) Retinoid X receptors orchestrate osteoclast differentiation and postnatal bone remodeling. J Clin Invest 125(2):809-23. doi:10.1172/JCI77186

9. Thomas M, Sukhai MA, Kamel-Reid S (2012) An emerging role for retinoid $\mathrm{X}$ receptor alpha in malignant hematopoiesis. Leukemia research 36(9):1075-81. doi:10.1016/j.leukres.2012.05.022

10. Yamada S, Kakuta H (2014) Retinoid X receptor ligands: a patent review (2007 - 2013). Expert opinion on therapeutic patents 24(4):443-52. doi:10.1517/13543776.2014.880692

11. Vaz B, De Lera AR (2012) Advances in drug design with RXR modulators. Expert opinion on drug discovery 7(11):1003-16. doi:10.1517/17460441.2012.722992

12. Mukherjee R, Davies PJ, Crombie DL, Bischoff ED, Cesario RM, Jow L, Hamann LG, Boehm MF, Mondon CE, Nadzan AM, Paterniti JR, Jr., Heyman RA (1997) Sensitization of diabetic and obese mice to insulin by retinoid $X$ receptor agonists. Nature 386(6623):407-10. doi:10.1038/386407a0

13. Dawson MI, Xia Z (2012) The retinoid X receptors and their ligands. $\begin{array}{lll}\text { Biochimica et } & \text { biophysica }\end{array}$ doi:10.1016/j.bbalip.2011.09.014 
1 14. Forman BM, Umesono K, Chen J, Evans RM (1995) Unique response pathways are established by allosteric interactions among nuclear hormone receptors. Cell 81:541-550.

15. Kurokawa R, Yu V, Näär A, Kyakumoto S, Han Z, Silverman S, Rosenfeld MG, Glass CK (1993) Differential orientations of the DNA binding domain and $\mathrm{C}$-terminal dimerization interface regulate binding site selection by nuclear receptor heterodimers. Genes and Dev. 7:14231435.

16. Campos-Melo D, Galleguillos D, Sanchez N, Gysling K, Andres ME (2013) Nur transcription factors in stress and addiction. Frontiers in molecular neuroscience 6:44. doi:10.3389/fnmol.2013.00044

17. Cho SD, Yoon K, Chintharlapalli S, Abdelrahim M, Lei P, Hamilton S, Khan S, Ramaiah SK, Safe S (2007) Nur77 agonists induce proapoptotic genes and responses in colon cancer cells through nuclear receptordependent and nuclear receptor-independent pathways. Cancer research 67(2):674-83. doi:10.1158/0008-5472.CAN-06-2907

18. Zhan Y, Du X, Chen H, Liu J, Zhao B, Huang D, Li G, Xu Q, Zhang M, Weimer BC, Chen D, Cheng Z, Zhang L, Li Q, Li S, Zheng Z, Song S, Huang Y, Ye Z, Su W, Lin SC, Shen Y, Wu Q (2008) Cytosporone B is an agonist for nuclear orphan receptor Nur77. Nature chemical biology 4(9):548-56. doi:10.1038/nchembio.106

19. De Miranda BR, Popichak KA, Hammond SL, Jorgensen BA, Phillips AT, Safe S, Tjalkens RB (2015) The Nurr1 Activator 1,1-Bis(3'-Indolyl)-1-(pChlorophenyl)Methane Blocks Inflammatory Gene Expression in BV-2 
Microglial Cells by Inhibiting Nuclear Factor kappaB. Molecular pharmacology 87(6):1021-34. doi:10.1124/mol.114.095398

20. Leblanc BP, Stunnenberg HG (1995) 0-Cis retinoic acid signaling: changing partners causes some excitement. Genes \& Dev. 9:1811-1816.

21. Lala DS, Mukherjee R, Schulman IG, Koch SS, Dardashti LJ, Nadzan AM, Croston GE, Evans RM, Heyman RA (1996) Activation of specific RXR heterodimers by an antagonist of RXR homodimers. Nature 383(6599):450-3.

22. Feige JN, Gelman L, Tudor C, Engelborghs Y, Wahli W, Desvergne B (2005) Fluorescence imaging reveals the nuclear behavior of peroxisome proliferator-activated receptor/retinoid $\mathrm{X}$ receptor heterodimers in the absence and presence of ligand. The Journal of biological chemistry 280(18):17880-90. doi:10.1074/jbc.M500786200

23. Chen ZP, Iyer J, Bourguet W, Held P, Mioskowski C, Lebeau L, Noy N, Chambon P, Gronemeyer H (1998) Ligand- and DNA-induced dissociation of RXR tetramers. J. Mol. Biol. 275(1):55-65.

24. Ijpenberg A, Tan NS, Gelman L, Kersten S, Seydoux J, Xu J, Metzger D, Canaple L, Chambon P, Wahli W, Desvergne B (2004) In vivo activation of PPAR target genes by RXR homodimers. Embo J 23(10):2083-91.

25. Mangelsdorf DJ, Ong ES, Dyck JA, Evans RM (1990) Nuclear receptor that identifies a novel retinoic acid response pathway. Nature 345:224229.

26. Heyman RA, Mangelsdorf DJ, Dyck JA, Stein RB, Eichele G, Evans RM, Thaller C (1992) 9-cis retinoic acid is a high affinity ligand for the retinoid X receptor. Cell 68:397-406. 
$127 . \quad W o l f \mathrm{G}(2006)$ Is 9-cis-retinoic acid the endogenous ligand for the retinoic acid-X receptor? Nutrition reviews 64(12):532-8.

28. Perez E, Bourguet W, Gronemeyer H, De Lera AR (2012) Modulation of RXR function through ligand design. Biochimica et biophysica acta 1821(1):57-69. doi:10.1016/j.bbalip.2011.04.003

29. Ziouzenkova O, Orasanu G, Sharlach M, Akiyama TE, Berger JP, Viereck J, Hamilton JA, Tang G, Dolnikowski GG, Vogel S, Duester G, Plutzky J (2007) Retinaldehyde represses adipogenesis and diet-induced obesity. Nature Medicine 13(6):695-702. doi:10.1038/nm1587

30. Ziouzenkova O, Orasanu G, Sukhova G, Lau E, Berger JP, Tang G, Krinsky NI, Dolnikowski GG, Plutzky J (2007) Asymmetric cleavage of beta-carotene yields a transcriptional repressor of retinoid $\mathrm{X}$ receptor and peroxisome proliferator-activated receptor responses. Molecular endocrinology 21(1):77-88. doi:10.1210/me.2006-0225

31. Moise AR, Alvarez S, Dominguez M, Alvarez R, Golczak M, Lobo GP, Von Lintig J, De Lera AR, Palczewski K (2009) Activation of retinoic acid receptors by dihydroretinoids. Molecular pharmacology 76(6):1228-37. doi:10.1124/mol.109.060038

32. Ruhl R, Krzyzosiak A, Niewiadomska-Cimicka A, Rochel N, Szeles L, Vaz B, Wietrzych-Schindler M, Alvarez S, Szklenar M, Nagy L, De Lera AR, Krezel W (2015) 9-cis-13,14-Dihydroretinoic Acid Is an Endogenous Retinoid Acting as RXR Ligand in Mice. PLoS genetics 11(6):e1005213. doi:10.1371/journal.pgen.1005213

33. Tsuji M, Shudo K, Kagechika H (2015) Docking simulations suggest that all-trans retinoic acid could bind to retinoid $X$ receptors. Journal of 
computer-aided molecular design 29(10):975-88. doi:10.1007/s10822015-9869-9

34. Mehta K, Mcqueen T, Neamati N, Collins S, Andreeff M (1996) Activation of retinoid receptors RAR alpha and RXR alpha induces differentiation and apoptosis, respectively, in HL-60 cells. Cell Growth Differ 7(2):17986.

35. Duvic M, Hymes K, Heald P, Breneman D, Martin AG, Myskowski P, Crowley C, Yocum RC (2001) Bexarotene is effective and safe for treatment of refractory advanced-stage cutaneous T-cell lymphoma: multinational phase II-III trial results. Journal of clinical oncology : official journal of the American Society of Clinical Oncology 19(9):2456-71.

36. Szanto A, Narkar V, Shen Q, Uray IP, Davies PJ, Nagy L (2004) Retinoid $X$ receptors: X-ploring their (patho)physiological functions. Cell Death Differ 11 Suppl 2:S126-43.

37. Yasmin R, Kannan-Thulasiraman P, Kagechika H, Dawson MI, Noy N (2010) Inhibition of mammary carcinoma cell growth by RXR is mediated by the receptor's oligomeric switch. Journal of molecular biology 397(5):1121-31. doi:10.1016/j.jmb.2010.02.030

38. Marshall PA, Jurutka PW, Wagner CE, Van Der Vaart A, Kaneko I, Chavez PI, Ma N, Bhogal JS, Shahani P, Swierski JC, Macneill M (2015) Analysis of differential secondary effects of novel rexinoids: select rexinoid $\mathrm{X}$ receptor ligands demonstrate differentiated side effect profiles. Pharmacology research \& perspectives 3(2):e00122. doi:10.1002/prp2.122 
1 39. Levine MA (2012) Assessing bone health in children and adolescents. Indian journal of endocrinology and metabolism 16(Suppl 2):S205-12. doi:10.4103/2230-8210.104040

40. Weitzmann MN, Ofotokun I (2016) Physiological and pathophysiological bone turnover - role of the immune system. Nature reviews. Endocrinology 12(9):518-32. doi:10.1038/nrendo.2016.91

41. Krakauer JC, Mckenna MJ, Buderer NF, Rao DS, Whitehouse FW, Parfitt AM (1995) Bone loss and bone turnover in diabetes. Diabetes 44(7):77582.

42. Lecka-Czernik B (2010) Bone loss in diabetes: use of antidiabetic thiazolidinediones and secondary osteoporosis. Current osteoporosis reports 8(4):178-84. doi:10.1007/s11914-010-0027-y

43. Teitelbaum SL (2000) Bone resorption by osteoclasts. Science 289(5484):1504-8.

44. Bucay N, Sarosi I, Dunstan CR, Morony S, Tarpley J, Capparelli C, Scully S, Tan HL, Xu W, Lacey DL, Boyle WJ, Simonet WS (1998) osteoprotegerin-deficient mice develop early onset osteoporosis and arterial calcification. Genes \& development 12(9):1260-8.

45. Imai Y, Youn MY, Inoue K, Takada I, Kouzmenko A, Kato S (2013) Nuclear receptors in bone physiology and diseases. Physiological reviews 93(2):481-523. doi:10.1152/physrev.00008.2012

46. Jin Z, Li X, Wan Y (2015) Minireview: nuclear receptor regulation of osteoclast and bone remodeling. Molecular endocrinology 29(2):172-86. doi:10.1210/me.2014-1316 
1 47. Kato S, Suzawa M, Takada I, Takeyama K, Yanagizawa J, Fujiki R, Kitagawa H (2003) The function of nuclear receptors in bone tissues. Journal of bone and mineral metabolism 21(6):323-36. doi:10.1007/s00774-003-0453-3

48. Harvey NC, Sheppard A, Godfrey KM, Mclean C, Garratt E, Ntani G, Davies L, Murray R, Inskip HM, Gluckman PD, Hanson MA, Lillycrop KA, Cooper C (2014) Childhood bone mineral content is associated with methylation status of the RXRA promoter at birth. Journal of bone and mineral research : the official journal of the American Society for Bone and Mineral Research 29(3):600-7. doi:10.1002/jbmr.2056

49. Evans RM, Mangelsdorf DJ (2014) Nuclear Receptors, RXR, and the Big Bang. Cell 157(1):255-66. doi:10.1016/j.cell.2014.03.012

50. Lefebvre $\mathrm{P}$, Benomar $\mathrm{Y}$, Staels B (2010) Retinoid X receptors: common heterodimerization partners with distinct functions. Trends Endocrinol Metab 21(11):676-83. doi:10.1016/j.tem.2010.06.009

51. Pirih FQ, Abayahoudian R, Elashoff D, Parhami F, Nervina JM, Tetradis S (2008) Nuclear receptor profile in calvarial bone cells undergoing osteogenic versus adipogenic differentiation. Journal of cellular biochemistry 105(5):1316-26. doi:10.1002/jcb.21931

52. Cho HY, Jung JY, Park H, Yang JY, Jung S, An JH, Cho SW, Kim SW, Kim SY, Kim JE, Park YJ, Shin CS (2014) In vivo deletion of CAR resulted in high bone mass phenotypes in male mice. Journal of cellular physiology 229(5):561-71. doi:10.1002/jcp.24478

53. Tabb MM, Sun A, Zhou C, Grun F, Errandi J, Romero K, Pham H, Inoue S, Mallick S, Lin M, Forman BM, Blumberg B (2003) Vitamin K2 
regulation of bone homeostasis is mediated by the steroid and xenobiotic receptor SXR. The Journal of biological chemistry 278(45):43919-27. doi:10.1074/jbc.M303136200

54. Wang Y, Zhu J, Deluca HF (2014) Identification of the vitamin D receptor in osteoblasts and chondrocytes but not osteoclasts in mouse bone. Journal of bone and mineral research : the official journal of the American Society for Bone and Mineral Research 29(3):685-92. doi:10.1002/jbmr.2081

55. Roforth MM, Liu G, Khosla S, Monroe DG (2012) Examination of nuclear receptor expression in osteoblasts reveals Rorbeta as an important regulator of osteogenesis. Journal of bone and mineral research : the official journal of the American Society for Bone and Mineral Research 27(4):891-901. doi:10.1002/jbmr.1502

56. Id Boufker H, Lagneaux L, Fayyad-Kazan H, Badran B, Najar M, Wiedig M, Ghanem G, Laurent G, Body JJ, Journe F (2011) Role of farnesoid X receptor $(F X R)$ in the process of differentiation of bone marrow stromal cells into osteoblasts. Bone 49(6):1219-31. doi:10.1016/j.bone.2011.08.013

57. Rőszer T, Menendez-Gutierrez MP, Cedenilla M, Ricote M (2013) Retinoid $X$ receptors in macrophage biology. Trends Endocrinol Metabdoi:S1043-2760(13)00078-7 [pii]

10.1016/j.tem.2013.04.004

58. Giaginis C, Tsantili-Kakoulidou A, Theocharis S (2007) Peroxisome proliferator-activated receptors (PPARs) in the control of bone 
metabolism. Fundamental \& clinical pharmacology 21(3):231-44. doi:10.1111/j.1472-8206.2007.00486.x

59. Wei W, Zeve D, Wang X, Du Y, Tang W, Dechow PC, Graff JM, Wan Y (2011) Osteoclast progenitors reside in the peroxisome proliferatoractivated receptor gamma-expressing bone marrow cell population. Molecular and cellular biology 31(23):4692-705. doi:10.1128/MCB.05979-11

60. Robertson KM, Norgard M, Windahl SH, Hultenby K, Ohlsson C, Andersson G, Gustafsson JA (2006) Cholesterol-sensing receptors, liver $\mathrm{X}$ receptor alpha and beta, have novel and distinct roles in osteoclast differentiation and activation. J Bone Miner Res 21(8):1276-87. doi:10.1359/jbmr.060503

61. Cho SW, An JH, Park H, Yang JY, Choi HJ, Kim SW, Park YJ, Kim SY, Yim M, Baek WY, Kim JE, Shin CS (2013) Positive regulation of osteogenesis by bile acid through FXR. Journal of bone and mineral research : the official journal of the American Society for Bone and Mineral Research 28(10):2109-21. doi:10.1002/jbmr.1961

62. Azuma K, Casey SC, Ito M, Urano T, Horie K, Ouchi Y, Kirchner S, Blumberg B, Inoue S (2010) Pregnane X receptor knockout mice display osteopenia with reduced bone formation and enhanced bone resorption. The Journal of endocrinology 207(3):257-63. doi:10.1677/JOE-10-0208

63. Li X, Wei W, Huynh H, Zuo H, Wang X, Wan Y (2015) Nur77 prevents excessive osteoclastogenesis by inducing ubiquitin ligase $\mathrm{Cbl}-\mathrm{b}$ to mediate NFATc1 self-limitation. eLife 4:e07217. doi:10.7554/eLife.07217 
1 64. Kastner P, Grondona JM, Mark M, Gansmuller A, Lemeur M, Decimo D, Vonesch JL, Dolle P, Chambon P (1994) Genetic analysis of RXR alpha developmental function: convergence of RXR and RAR signaling pathways in heart and eye morphogenesis. Cell 78(6):987-1003.

65. Kastner P, Mark M, Leid M, Gansmuller A, Chin W, Grondona JM, Decimo D, Krezel W, Dierich A, Chambon P (1996) Abnormal spermatogenesis in RXR beta mutant mice. Genes \& development 10(1):80-92.

66. Haugen BR, Jensen DR, Sharma V, Pulawa LK, Hays WR, Krezel W, Chambon P, Eckel RH (2004) Retinoid X receptor gamma-deficient mice have increased skeletal muscle lipoprotein lipase activity and less weight gain when fed a high-fat diet. Endocrinology 145(8):3679-85. doi:10.1210/en.2003-1401

67. Gilardi F, Desvergne B (2014) RXRs: collegial partners. Sub-cellular biochemistry 70:75-102. doi:10.1007/978-94-017-9050-5_5

68. Ricote M, Snyder CS, Leung HY, Chen J, Chien KR, Glass CK (2006) Normal hematopoiesis after conditional targeting of RXRalpha in murine hematopoietic stem/progenitor cells. J Leukoc Biol 80(4):850-61.

69. Rahman MM, Bhattacharya A, Banu J, Kang JX, Fernandes G (2009) Endogenous n-3 fatty acids protect ovariectomy induced bone loss by attenuating osteoclastogenesis. Journal of cellular and molecular medicine 13(8B):1833-44. doi:10.1111/j.1582-4934.2009.00649.x

70. Kelly OJ, Gilman JC, Kim Y, llich JZ (2013) Long-chain polyunsaturated fatty acids may mutually benefit both obesity and osteoporosis. Nutr Res 33(7):521-33. doi:10.1016/j.nutres.2013.04.012 
S0271-5317(13)00095-X [pii]

71. Bell TD, Demay MB, Burnett-Bowie SA The biology and pathology of vitamin $\mathrm{D}$ control in bone. J Cell Biochem 111(1):7-13. doi:10.1002/jcb.22661

72. Cardoso LF, Maciel LM, Paula FJ (2014) The multiple effects of thyroid disorders on bone and mineral metabolism. Arquivos brasileiros de endocrinologia e metabologia 58(5):452-63.

73. Williams GR (2013) Thyroid hormone actions in cartilage and bone. European thyroid journal 2(1):3-13. doi:10.1159/000345548

74. Scholtysek C, Katzenbeisser J, Fu H, Uderhardt S, Ipseiz N, Stoll C, Zaiss MM, Stock M, Donhauser L, Bohm C, Kleyer A, Hess A, Engelke K, David JP, Djouad F, Tuckermann JP, Desvergne B, Schett G, Kronke G (2013) PPARbeta/delta governs Wnt signaling and bone turnover. Nat Med 19(5):608-13. doi:10.1038/nm.3146

nm.3146 [pii]

75. Green AC, Poulton IJ, Vrahnas C, Hausler KD, Walkley CR, Wu JY, Martin TJ, Gillespie MT, Chandraratna RA, Quinn JM, Sims NA, Purton LE (2015) RARgamma is a negative regulator of osteoclastogenesis. The Journal of steroid biochemistry and molecular biology 150:46-53. doi:10.1016/j.jsbmb.2015.03.005

76. Malhotra D, Yang Y (2014) Wnts' fashion statement: from body stature to dysplasia. BoneKEy reports 3:541. doi:10.1038/bonekey.2014.36

77. Walker EC, Mcgregor NE, Poulton IJ, Pompolo S, Allan EH, Quinn JM, Gillespie MT, Martin TJ, Sims NA (2008) Cardiotrophin-1 is an osteoclast-derived stimulus of bone formation required for normal bone 
remodeling. Journal of bone and mineral research : the official journal of the American Society for Bone and Mineral Research 23(12):2025-32. doi:10.1359/jbmr.080706

78. Lees RL, Sabharwal VK, Heersche JN (2001) Resorptive state and cell size influence intracellular $\mathrm{pH}$ regulation in rabbit osteoclasts cultured on collagen-hydroxyapatite films. Bone 28(2):187-94.

79. Fujita K, Iwasaki M, Ochi H, Fukuda T, Ma C, Miyamoto T, Takitani K, Negishi-Koga T, Sunamura S, Kodama T, Takayanagi H, Tamai H, Kato S, Arai H, Shinomiya K, Itoh H, Okawa A, Takeda S (2012) Vitamin E decreases bone mass by stimulating osteoclast fusion. Nature medicine 18(4):589-94. doi:10.1038/nm.2659

80. Takayanagi $\mathrm{H}$ (2007) The role of NFAT in osteoclast formation. Annals of the New York Academy of Sciences 1116:227-37. doi:10.1196/annals.1402.071

81. Akune T, Ohba S, Kamekura S, Yamaguchi M, Chung UI, Kubota N, Terauchi Y, Harada Y, Azuma Y, Nakamura K, Kadowaki T, Kawaguchi H (2004) PPARgamma insufficiency enhances osteogenesis through osteoblast formation from bone marrow progenitors. J Clin Invest 113(6):846-55. doi:10.1172/JCl19900

82. Wan Y, Chong LW, Evans RM (2007) PPAR-gamma regulates osteoclastogenesis in mice. Nat Med 13(12):1496-503. doi:nm1672 [pii]

$10.1038 / \mathrm{nm} 1672$

83. Masuyama R, Stockmans I, Torrekens S, Van Looveren R, Maes C, Carmeliet P, Bouillon R, Carmeliet G (2006) Vitamin D receptor in chondrocytes promotes osteoclastogenesis and regulates FGF23 
production in osteoblasts. J Clin Invest 116(12):3150-9. doi:10.1172/JCl29463

84. Siersbaek R, Nielsen R, Mandrup S (2010) PPARgamma in adipocyte differentiation and metabolism--novel insights from genome-wide studies. FEBS letters 584(15):3242-9. doi:10.1016/j.febslet.2010.06.010

85. Murphy S, Khaw KT, Cassidy A, Compston JE (1993) Sex hormones and bone mineral density in elderly men. Bone and mineral 20(2):133-40.

86. Chen Q, Kaji H, Kanatani M, Sugimoto T, Chihara K (2004) Testosterone increases osteoprotegerin mRNA expression in mouse osteoblast cells. Hormone and metabolic research $=$ Hormon- und Stoffwechselforschung $=$ Hormones et metabolisme 36(10):674-8. doi:10.1055/s-2004-826013

87. Lu Y, Feng JQ (2011) FGF23 in skeletal modeling and remodeling. Current osteoporosis reports 9(2):103-8. doi:10.1007/s11914-011-0053-4

88. Green AC, Martin TJ, Purton LE (2016) The role of vitamin A and retinoic acid receptor signaling in post-natal maintenance of bone. The Journal of steroid biochemistry and molecular biology 155(Pt A):135-46. doi:10.1016/j.jsbmb.2015.09.036

89. Zhang X-K, Lehmann J, Hoffmann B, Dawson MI, Cameron J, Graupner G, Hermann T, Tran P, Pfahl M (1992) Homodimer formation of retinoid $\mathrm{X}$ receptor induced by 9-cis retinoic acid. Nature 358:587-591.

90. Kim K, Kim JH, Lee J, Jin HM, Kook H, Kim KK, Lee SY, Kim N (2007) MafB negatively regulates RANKL-mediated osteoclast differentiation. Blood 109(8):3253-9. doi:blood-2006-09-048249 [pii]10.1182/blood2006-09-048249 
1 91. Nowak B, Matuszewska A, Filipiak J, Nikodem A, Merwid-Lad A,

Piesniewska M, Fereniec-Golebiewska L, Kwiatkowska J, Szelag A (2016) The influence of bexarotene, a selective agonist of the retinoid receptor $X(R X R)$, and tazarotene, a selective agonist of the retinoid acid receptor (RAR), on bone metabolism in rats. Advances in medical sciences 61(1):85-9. doi:10.1016/j.advms.2015.09.001

92. Zhang W, Deng ZL, Chen L, Zuo GW, Luo Q, Shi Q, Zhang BQ, Wagner ER, Rastegar F, Kim SH, Jiang W, Shen J, Huang E, Gao Y, Gao JL, Zhou JZ, Luo J, Huang J, Luo X, Bi Y, Su Y, Yang K, Liu H, Luu HH, Haydon RC, He TC, He BC (2010) Retinoic acids potentiate BMP9induced osteogenic differentiation of mesenchymal progenitor cells. PLoS One 5(7):e11917. doi:10.1371/journal.pone.0011917

93. He BC, Chen L, Zuo GW, Zhang W, Bi Y, Huang J, Wang Y, Jiang W, Luo Q, Shi Q, Zhang BQ, Liu B, Lei X, Luo J, Luo X, Wagner ER, Kim SH, He CJ, Hu Y, Shen J, Zhou Q, Rastegar F, Deng ZL, Luu HH, He TC, Haydon RC (2010) Synergistic antitumor effect of the activated PPARgamma and retinoid receptors on human osteosarcoma. Clinical cancer research : an official journal of the American Association for Cancer Research 16(8):2235-45. doi:10.1158/1078-0432.CCR-09-2499

94. Kneissel M, Studer A, Cortesi R, Susa M (2005) Retinoid-induced bone thinning is caused by subperiosteal osteoclast activity in adult rodents. Bone 36(2):202-14. doi:S8756-3282(04)00451-X [pii]

10.1016/j.bone.2004.11.006

95. Baker AH, Watt J, Huang CK, Gerstenfeld LC, Schlezinger JJ (2015) Tributyltin engages multiple nuclear receptor pathways and suppresses 
osteogenesis in bone marrow multipotent stromal cells. Chemical research in toxicology 28(6):1156-66. doi:10.1021/tx500433r

96. Xiao JH, Ghosn C, Hinchman C, Forbes C, Wang J, Snider N, Cordrey A, Zhao Y, Chandraratna RA (2003) Adenomatous polyposis coli (APC)independent regulation of beta-catenin degradation via a retinoid $X$ receptor-mediated pathway. The Journal of biological chemistry 278(32):29954-62. doi:10.1074/jbc.M304761200

97. Xu L, Song C, Ni M, Meng F, Xie H, Li G (2012) Cellular retinol-binding protein 1 (CRBP-1) regulates osteogenenesis and adipogenesis of mesenchymal stem cells through inhibiting RXRalpha-induced betacatenin degradation. The international journal of biochemistry \& cell biology 44(4):612-9. doi:10.1016/j.biocel.2011.12.018

98. Eberle D, Hegarty B, Bossard P, Ferre P, Foufelle F (2004) SREBP transcription factors: master regulators of lipid homeostasis. Biochimie 86(11):839-48. doi:10.1016/j.biochi.2004.09.018

99. Remen KM, Henning P, Lerner UH, Gustafsson JA, Andersson G (2011) Activation of liver $\mathrm{X}$ receptor $(\mathrm{LXR})$ inhibits receptor activator of nuclear factor kappaB ligand (RANKL)-induced osteoclast differentiation in an LXRbeta-dependent mechanism. The Journal of biological chemistry 286(38):33084-94. doi:10.1074/jbc.M111.235937

100. Kleyer A, Scholtysek C, Bottesch E, Hillienhof U, Beyer C, Distler JH, Tuckermann JP, Schett G, Kronke G (2012) Liver X receptors orchestrate osteoblast/osteoclast crosstalk and counteract pathologic bone loss. Journal of bone and mineral research : the official journal of 
the American Society for Bone and Mineral Research 27(12):2442-51. doi:10.1002/jbmr.1702

101. Prawitt J, Beil FT, Marshall RP, Bartelt A, Ruether W, Heeren J, Amling M, Staels B, Niemeier A Short-term activation of liver X receptors inhibits osteoblasts but long-term activation does not have an impact on murine bone in vivo. Bone 48(2):339-46. doi:S8756-3282(10)01436-5 [pii]

10.1016/j.bone.2010.08.018

102. Still K, Grabowski P, Mackie I, Perry M, Bishop N (2008) The peroxisome proliferator activator receptor alpha/delta agonists linoleic acid and bezafibrate upregulate osteoblast differentiation and induce periosteal bone formation in vivo. Calcified tissue international 83(4):285-92. doi:10.1007/s00223-008-9175-9

103. Chan BY, Gartland A, Wilson PJ, Buckley KA, Dillon JP, Fraser WD, Gallagher JA (2007) PPAR agonists modulate human osteoclast formation and activity in vitro. Bone 40(1):149-59. doi:10.1016/j.bone.2006.07.029

104. Mano H, Kimura C, Fujisawa Y, Kameda T, Watanabe-Mano M, Kaneko H, Kaneda T, Hakeda Y, Kumegawa M (2000) Cloning and function of rabbit peroxisome proliferator-activated receptor delta/beta in mature osteoclasts. J Biol Chem 275(11):8126-32.

105. Kawai M, Sousa KM, Macdougald OA, Rosen CJ (2010) The many facets of PPARgamma: novel insights for the skeleton. American journal of physiology. Endocrinology and metabolism 299(1):E3-9. doi:10.1152/ajpendo.00157.2010 
1 106. Wan Y (2010) PPARgamma in bone homeostasis. Trends in endocrinology and metabolism: TEM 21(12):722-8. doi:10.1016/j.tem.2010.08.006

107. Falchetti A, Masi L, Brandia ML (2007) Thiazolidinediones and bone. Clinical cases in mineral and bone metabolism : the official journal of the Italian Society of Osteoporosis, Mineral Metabolism, and Skeletal Diseases 4(2):103-7.

108. Miki T, Nakatsuka K, Naka H, Kitatani K, Saito S, Masaki H, Tomiyoshi Y, Morii H, Nishizawa Y (2003) Vitamin K(2) (menaquinone 4) reduces serum undercarboxylated osteocalcin level as early as 2 weeks in elderly women with established osteoporosis. Journal of bone and mineral metabolism 21(3):161-5. doi:10.1007/s007740300025

109. Ichikawa T, Horie-Inoue K, Ikeda K, Blumberg B, Inoue S (2006) Steroid and xenobiotic receptor SXR mediates vitamin K2-activated transcription of extracellular matrix-related genes and collagen accumulation in osteoblastic cells. The Journal of biological chemistry 281(25):16927-34. doi:10.1074/jbc.M600896200

110. Wu X, Peters JM, Gonzalez FJ, Prasad HS, Rohrer MD, Gimble JM (2000) Frequency of stromal lineage colony forming units in bone marrow of peroxisome proliferator-activated receptor-alpha-null mice. Bone 26(1):21-6.

111. Jiang C, Wan X, He Y, Pan T, Jankovic J, Le W (2005) Age-dependent dopaminergic dysfunction in Nurr1 knockout mice. Experimental Neurology 191(1):154-62. doi:10.1016/j.expneurol.2004.08.035 
1 112. Bassett JH, O'shea PJ, Sriskantharajah S, Rabier B, Boyde A, Howell PG, Weiss RE, Roux JP, Malaval L, Clement-Lacroix P, Samarut J, Chassande O, Williams GR (2007) Thyroid hormone excess rather than thyrotropin deficiency induces osteoporosis in hyperthyroidism. Molecular endocrinology 21(5):1095-107. doi:10.1210/me.2007-0033

113. Yoshizawa T, Handa Y, Uematsu Y, Takeda S, Sekine K, Yoshihara Y, Kawakami T, Arioka K, Sato H, Uchiyama Y, Masushige S, Fukamizu A, Matsumoto T, Kato S (1997) Mice lacking the vitamin D receptor exhibit impaired bone formation, uterine hypoplasia and growth retardation after weaning. Nature genetics 16(4):391-6. doi:10.1038/ng0897-391

114. Amling M, Priemel M, Holzmann T, Chapin K, Rueger JM, Baron R, Demay MB (1999) Rescue of the skeletal phenotype of vitamin D receptor-ablated mice in the setting of normal mineral ion homeostasis: formal histomorphometric and biomechanical analyses. Endocrinology 140(11):4982-7. doi:10.1210/endo.140.11.7110

115. Ali AA, Weinstein RS, Stewart SA, Parfitt AM, Manolagas SC, Jilka RL (2005) Rosiglitazone causes bone loss in mice by suppressing osteoblast differentiation and bone formation. Endocrinology 146(3):1226-35. doi:10.1210/en.2004-0735

116. Rzonca SO, Suva LJ, Gaddy D, Montague DC, Lecka-Czernik B (2004) Bone is a target for the antidiabetic compound rosiglitazone. Endocrinology 145(1):401-6. doi:10.1210/en.2003-0746

117. Shockley KR, Lazarenko OP, Czernik PJ, Rosen CJ, Churchill GA, Lecka-Czernik B (2009) PPARgamma2 nuclear receptor controls multiple regulatory pathways of osteoblast differentiation from marrow 
mesenchymal stem cells. Journal of cellular biochemistry 106(2):232-46.

2 doi:10.1002/jcb.21994

3 118. Cho ES, Kim MK, Son YO, Lee KS, Park SM, Lee JC (2012) The effects of rosiglitazone on osteoblastic differentiation, osteoclast formation and bone resorption. Molecules and cells 33(2):173-81. doi:10.1007/s10059-

6 012-2240-z 


\section{$1 \quad$ Figure legends}

2

3 Figure 1: RXR-mediated regulation of bone remodeling. Blue arrows indicate 4 genes or processes activated by RXR dimers, and red arrows represent 5 repressive actions of $\mathrm{RXR}$ dimers (continuous line: bone fide target gene; 6 dotted line: undefined mechanism).

7

8 Table 1: RXRs and heterodimer partners expressed in the osteoblast and 9 osteoclast lineages

11 Table 2: Adult bone phenotypes of knockout mice for RXR and RXR-partners

13 Table 3: Effects of agonists of RXRs and their permissive heterodimer partners 14 on osteoclast and osteoblast differentiation or activity 


\begin{tabular}{|c|c|c|c|c|c|c|}
\hline NR & Isotypes & Osteoblast & Osteoclast & Natural ligands & Synthetic ligands & DR \\
\hline \multirow{3}{*}{ RXR } & $\alpha$ (NR2B1) & $E[51]$ & $E[57]$ & \multirow{3}{*}{$\begin{array}{l}\text { Retinoids } \\
\text { Fatty acids }\end{array}$} & \multirow{3}{*}{$\begin{array}{l}\text { Rexinoids } \\
\text { Tributyltin }\end{array}$} & \multirow{3}{*}{ DR-1 } \\
\hline & $\beta$ (NR2B2) & $E[51]$ & $E[57]$ & & & \\
\hline & $\gamma($ NR2B3) & $E[51]$ & $\mathrm{NE}[57]$ & & & \\
\hline \multirow{3}{*}{ PPAR } & $\alpha(\mathrm{NR} 1 \mathrm{C} 1)$ & $E$ [51] & $E[58]$ & $\begin{array}{l}\text { Arachidonic acid } \\
\text { metabolites } \\
\text { Linoleic acid }\end{array}$ & $\begin{array}{c}\text { GW7647 } \\
\text { Fibrate derivatives }\end{array}$ & \multirow{3}{*}{ DR-1 } \\
\hline & $\begin{array}{c}\beta / \delta \\
(\mathrm{NR} 1 \mathrm{C} 2)\end{array}$ & $E$ [51] & $E[45,57]$ & $\begin{array}{l}\text { Prostaglandin } 12 \\
\text { Carbaprostacyclin }\end{array}$ & $\begin{array}{c}\text { GW0742 } \\
\text { L165041 } \\
\text { GW501516 }\end{array}$ & \\
\hline & Y (NR1C3) & $E$ [51] & $E[57,59]$ & Fatty acids & $\begin{array}{c}\text { TZD } \\
\text { GW9662 } \\
\text { THR0921 } \\
\text { CLX-090717 } \\
\text { Tributyltin }\end{array}$ & \\
\hline \multirow{2}{*}{ LXR } & $\alpha$ (NR1H1) & $E[57,60]$ & $E[57,60]$ & Oxysterols & GW3965 & \\
\hline & $\beta(\mathrm{NR} 1 \mathrm{H} 2)$ & $E[57,60]$ & $E[57,60]$ & Uxysterols & $\begin{array}{c}\text { T0901317 } \\
\text { Fexaramine }\end{array}$ & DR-4 \\
\hline FXR & $\mathrm{NR} 1 \mathrm{H} 4$ & $E[51,56]$ & $E[61]$ & $\begin{array}{l}\text { Farnesol } \\
\text { Bile acids }\end{array}$ & $\begin{array}{l}\text { 6E-CDCA } \\
\text { GW406 }\end{array}$ & IR-1 \\
\hline PXR & NR112 & E [109] & E [62] & $\begin{array}{l}\text { Xenobiotics } \\
\text { Vitamin K2 } \\
\text { Sterols and their } \\
\text { metabolites }\end{array}$ & $\begin{array}{c}\text { Rifampicin } \\
\text { Hyperforin } \\
\text { Taxol } \\
\text { Phenobarbital } \\
\text { Ritonavir } \\
\text { Carbamazipine }\end{array}$ & $\begin{array}{l}\text { DR-3-5 } \\
\text { IR-6 } \\
\text { ER-6,8 }\end{array}$ \\
\hline CAR & NR113 & $E[52]$ & $E[52]$ & $\begin{array}{c}\text { Xenobiotics } \\
\text { Endobiotics } \\
\text { Steroid hormones }\end{array}$ & $\begin{array}{c}\text { Wy-14,643 } \\
\text { Ciprofibrate } \\
\text { Clofibrate }\end{array}$ & $\begin{array}{l}\text { DR-4 } \\
\text { DR-5 }\end{array}$ \\
\hline Nur77 & NR4A1 & $E$ [51] & $E[57,63]$ & Not known & $\begin{array}{c}\text { DIMs [17] } \\
\text { Citosporone B [18 }\end{array}$ & DR-5 \\
\hline Nurr1 & NR4A2 & $E[51]$ & NE [63] & Not known & DIMs [19] & DR-5 \\
\hline \multirow{3}{*}{ RAR } & $\alpha$ (NR1B1) & $E[51]$ & $E[57]$ & \multirow{3}{*}{ Retinoids } & \multirow{3}{*}{$\begin{array}{l}\text { AM580 } \\
\text { TTNPB }\end{array}$} & \multirow{3}{*}{$\begin{array}{l}\text { DR-2 } \\
\text { DR-5 }\end{array}$} \\
\hline & $\beta$ (NR1B2) & $E[51]$ & $E[57]$ & & & \\
\hline & Y (NR1B3) & $E[51]$ & $E[57]$ & & & \\
\hline \multirow{2}{*}{ TR } & $\alpha$ (NR1A1) & $E[51,110]$ & $E[57]$ & \multirow{2}{*}{ Thyroid hormones } & \multirow{2}{*}{$\begin{array}{c}\text { GC-1 } \\
\text { KB141 } \\
\text { GC-24 } \\
\end{array}$} & \multirow{2}{*}{ DR-4 } \\
\hline & $\beta(N R 1 A 2)$ & $E[51,110]$ & $E$ [57] & & & \\
\hline VDR & NR111 & $E[54]$ & NE [54] & $1,25(\mathrm{OH})_{2} \mathrm{VD}_{3}$ & MC903 & DR-3 \\
\hline
\end{tabular}

Green: permissive RXR heterodimer partners; Blue: non-permissive RXR heterodimer partners. 


\begin{tabular}{|c|c|c|c|c|c|c|}
\hline NR & Mouse model & Cell type & $\begin{array}{c}\text { Bone } \\
\text { phenotype }\end{array}$ & $\begin{array}{l}\text { Bone } \\
\text { mineral } \\
\text { density }\end{array}$ & $\begin{array}{l}\text { Bone } \\
\text { resorption }\end{array}$ & $\begin{array}{c}\text { Bone } \\
\text { formation }\end{array}$ \\
\hline \multirow{4}{*}{ RXR } & ${ }^{*} \mathrm{Rxra}^{-1-}[64]$ & Systemic & - & - & - & - \\
\hline & $\mathrm{Rxrb}^{-1-}[65]$ & Systemic & Normal & NA & NA & NA \\
\hline & $\operatorname{Rxrg}^{-1-}[66]$ & Systemic & Normal & NA & NA & NA \\
\hline & $\begin{array}{c}M \times 1-C r e / R \times r a^{f / / f l} b^{f / f l} \\
{[8]}\end{array}$ & $\begin{array}{l}\text { Osteoclast } \\
\text { lineage }\end{array}$ & $\begin{array}{l}\text { Increased } \\
\text { bone mass }\end{array}$ & $\begin{array}{l}\text { Male } \uparrow \\
\text { Female } \\
\rightarrow\end{array}$ & $\downarrow$ & $\rightarrow$ \\
\hline \multirow{4}{*}{ PPAR } & Ppara $^{-/-}[110]$ & Systemic & Normal & $\rightarrow$ & $\rightarrow$ & $\rightarrow$ \\
\hline & Ppard ${ }^{\text {Sox2-cko }}[74]$ & $\begin{array}{l}\text { Systemic } \\
\text { (except } \\
\text { placenta) }\end{array}$ & Osteopenia & $\downarrow$ & $\uparrow$ & $\rightarrow$ \\
\hline & Pparg $^{+/-}[81]$ & Systemic & $\begin{array}{c}\text { Increased } \\
\text { bone mass } \\
\text { Osteopetrosis }\end{array}$ & $\uparrow$ & $\rightarrow$ & $\uparrow$ \\
\hline & Tie2Cre/Pparg ${ }^{\mathrm{fl} / f 1}[82]$ & $\begin{array}{l}\text { Osteoclast } \\
\text { lineage }\end{array}$ & $\begin{array}{l}\text { Increased } \\
\text { bone mass }\end{array}$ & $\uparrow$ & $\downarrow$ & $\rightarrow$ \\
\hline \multirow{3}{*}{ LXR } & $\mathrm{Lxra}^{-/-}[60]$ & Systemic & $\begin{array}{l}\text { Increased } \\
\text { bone mass }\end{array}$ & $\begin{array}{c}\text { Male } \rightarrow \\
\text { Female } \uparrow\end{array}$ & $\downarrow$ & $\rightarrow$ \\
\hline & $\mathrm{Lxrb}^{-1-}[60]$ & Systemic & Normal & $\rightarrow$ & $\downarrow$ & $\uparrow$ \\
\hline & Lxrab $^{-1-}[60]$ & Systemic & Normal & $\rightarrow$ & $\rightarrow$ & $\rightarrow$ \\
\hline FXR & $\mathrm{Fxr}^{-1-}[61]$ & Systemic & Osteopenia & $\begin{array}{c}\text { Male } \downarrow \\
\text { Female } \\
\rightarrow\end{array}$ & $\uparrow$ & $\downarrow$ \\
\hline PXR & $\mathrm{Pxr}^{-1-}[62]$ & Systemic & Osteopenia & $\begin{array}{c}\text { Male ? } \\
\text { Female } \downarrow\end{array}$ & $\uparrow$ & $\downarrow$ \\
\hline CAR & $\mathrm{Car}^{-1-}[52]$ & Systemic & $\begin{array}{l}\text { Increased } \\
\text { bone mass }\end{array}$ & $\begin{array}{l}\text { Male } \uparrow \\
\text { Female } \\
\rightarrow\end{array}$ & $\rightarrow$ & $\uparrow ?$ \\
\hline Nur77 & Nurr777-I- [63] & Systemic & Osteopenia & $\downarrow$ & $\uparrow$ & $\rightarrow$ \\
\hline Nurr1 & Nurr1 ${ }^{+/-}[111]$ & Systemic & Normal & NA & NA & NA \\
\hline \multirow{3}{*}{ RAR } & Rara $^{-l-}[75]$ & Systemic & Normal & $\rightarrow$ & $\rightarrow$ & $\rightarrow$ \\
\hline & Rarb $^{-1-}$ & Systemic & Normal & NA & NA & NA \\
\hline & $\operatorname{Rarg}^{-1-}[75]$ & Systemic & Osteopenia & $\downarrow$ & $\uparrow$ & $?$ \\
\hline \multirow{2}{*}{ TR } & $\mathrm{TRa}^{-1-}[112]$ & Systemic & Osteosclerosi & $\uparrow$ & $\downarrow$ & NA \\
\hline & $\mathrm{TRb}^{-/-}[112]$ & Systemic & Osteoporosis & $\downarrow$ & $\uparrow$ & NA \\
\hline \multirow{2}{*}{ VDR } & $\operatorname{VDR}^{-/-}[113,114]$ & Systemic & $\begin{array}{c}\text { Rickets } \\
\text { Osteomalacia }\end{array}$ & $\downarrow$ & $\rightarrow$ & $\uparrow$ \\
\hline & Col2Cre ${ }^{+/-V D R} R^{f / / f l}[83]$ & Chondrocyte & $\begin{array}{l}\text { Increased } \\
\text { bone mass }\end{array}$ & $\uparrow$ & $\downarrow$ & $\rightarrow$ \\
\hline
\end{tabular}

${ }^{\star}$ Embryonically lethal. NA: not assessed. Arrows indicate increase, decrease, or no change. 


\begin{tabular}{|c|c|c|c|}
\hline NR & Ligand & $\begin{array}{l}\text { Osteoclast } \\
\text { differentiation } \\
\text { or activity }\end{array}$ & $\begin{array}{l}\text { Osteoblast } \\
\text { differentiation } \\
\text { or activity }\end{array}$ \\
\hline \multirow{3}{*}{ RXRs } & LG100268 $(1,2)$ & $\downarrow^{a}$ & $\downarrow^{a}$ \\
\hline & Bexarotene $(1,2)$ & $\downarrow^{b}$ & $\rightarrow^{\mathrm{b}} \downarrow^{\mathrm{a}}$ \\
\hline & 9-cisRA (3-5) & & $\uparrow^{a} \downarrow^{a}$ \\
\hline \multirow{3}{*}{ PPAR $\alpha$} & Bezafibrate $(6,7)$ & $\uparrow^{a}$ & $\uparrow^{a}$ \\
\hline & Fenobbrate (7) & $\uparrow^{a}$ & \\
\hline & Linoleic acid (6) & & $\uparrow^{a}$ \\
\hline \multirow{3}{*}{ PPAR $\delta / \beta$} & Carbaprostacyclin (8) & $\uparrow^{\mathrm{a}}$ & \\
\hline & L165041 (7) & $\uparrow^{\mathrm{a}}$ & \\
\hline & GW501516 (9) & & $\uparrow^{a}$ \\
\hline \multirow{2}{*}{ PPAR $\gamma$} & Rosiglitazone (10-14) & $\uparrow^{\mathrm{a}, \mathrm{b}}$ & $\downarrow^{a, b}$ \\
\hline & Ciglitizone (7) & $\uparrow^{a}$ & \\
\hline \multirow{2}{*}{ LXRs } & GW3965(15) & $\downarrow^{\mathrm{a}} \rightarrow^{\mathrm{b}}$ & $\rightarrow^{\mathrm{b}}$ \\
\hline & T0901317 $(1,16,17)$ & $\downarrow^{\mathrm{a}} \rightarrow^{\mathrm{a}, \mathrm{b}}$ & $\mathrm{a,b} \rightarrow^{\mathrm{b}}$ \\
\hline \multirow{5}{*}{ FXR } & Chenodeoxycholic acid (18) & & $\uparrow^{a}$ \\
\hline & Farnesol (18) & & $\uparrow^{a}$ \\
\hline & Bile acids (19) & $\downarrow^{a}$ & $\uparrow^{a, b}$ \\
\hline & GW4064 (19) & $\downarrow^{\mathrm{a}}$ & $\uparrow^{a}$ \\
\hline & Fexaramine (19) & $\downarrow^{a}$ & $\uparrow^{\mathrm{a}}$ \\
\hline \multirow{3}{*}{ PXR } & Vitamin K2 (20) & & $\uparrow^{a}$ \\
\hline & Rifampicin (20) & & $\uparrow^{a}$ \\
\hline & Hyperforin (20) & & $\uparrow^{a}$ \\
\hline
\end{tabular}

a in vitro; ${ }^{b}$ in vivo. Arrows indicate increase, decrease, or no change.

1. Menendez-Gutierrez, M.P., Roszer, T., Fuentes, L., Nunez, V., Escolano, A., Redondo, J.M., De Clerck, N., Metzger, D., Valledor, A.F., and Ricote, M. 2015. Retinoid X receptors orchestrate osteoclast differentiation and postnatal bone remodeling. J Clin Invest 125:809-823.

2. Baker, A.H., Watt, J., Huang, C.K., Gerstenfeld, L.C., and Schlezinger, J.J. 2015. Tributyltin engages multiple nuclear receptor pathways and suppresses osteogenesis in bone marrow multipotent stromal cells. Chemical research in toxicology 28:11561166.

3. Kneissel, M., Studer, A., Cortesi, R., and Susa, M. 2005. Retinoid-induced bone thinning is caused by subperiosteal osteoclast activity in adult rodents. Bone 36:202-214.

4. He, B.C., Chen, L., Zuo, G.W., Zhang, W., Bi, Y., Huang, J., Wang, Y., Jiang, W., Luo, Q., Shi, Q., et al. 2010. Synergistic antitumor effect of the activated PPARgamma and retinoid receptors on human osteosarcoma. Clinical cancer research : an official journal of the American Association for Cancer Research 16:2235-2245.

5. Zhang, W., Deng, Z.L., Chen, L., Zuo, G.W., Luo, Q., Shi, Q., Zhang, B.Q., Wagner, E.R., Rastegar, F., Kim, S.H., et al. 2010. Retinoic acids potentiate BMP9-induced osteogenic differentiation of mesenchymal progenitor cells. PLoS One 5:e11917.

6. Still, K., Grabowski, P., Mackie, I., Perry, M., and Bishop, N. 2008. The peroxisome proliferator activator receptor alpha/delta agonists linoleic acid and bezafibrate upregulate osteoblast differentiation and induce periosteal bone formation in vivo. Calcified tissue international 83:285-292.

7. Chan, B.Y., Gartland, A., Wilson, P.J., Buckley, K.A., Dillon, J.P., Fraser, W.D., and Gallagher, J.A. 2007. PPAR agonists modulate human osteoclast formation and activity in vitro. Bone 40:149-159. 
8. Mano, H., Kimura, C., Fujisawa, Y., Kameda, T., Watanabe-Mano, M., Kaneko, H., Kaneda, T., Hakeda, Y., and Kumegawa, M. 2000. Cloning and function of rabbit peroxisome proliferator-activated receptor delta/beta in mature osteoclasts. J Biol Chem 275:8126-8132.

9. Scholtysek, C., Katzenbeisser, J., Fu, H., Uderhardt, S., Ipseiz, N., Stoll, C., Zaiss, M.M., Stock, M., Donhauser, L., Bohm, C., et al. 2013. PPARbeta/delta governs Wnt signaling and bone turnover. Nat Med 19:608-613.

10. Ali, A.A., Weinstein, R.S., Stewart, S.A., Parfitt, A.M., Manolagas, S.C., and Jilka, R.L. 2005. Rosiglitazone causes bone loss in mice by suppressing osteoblast differentiation and bone formation. Endocrinology 146:1226-1235.

11. Rzonca, S.O., Suva, L.J., Gaddy, D., Montague, D.C., and Lecka-Czernik, B. 2004. Bone is a target for the antidiabetic compound rosiglitazone. Endocrinology 145:401-406.

12. Wan, Y., Chong, L.W., and Evans, R.M. 2007. PPAR-gamma regulates osteoclastogenesis in mice. Nat Med 13:1496-1503.

13. Shockley, K.R., Lazarenko, O.P., Czernik, P.J., Rosen, C.J., Churchill, G.A., and LeckaCzernik, B. 2009. PPARgamma2 nuclear receptor controls multiple regulatory pathways of osteoblast differentiation from marrow mesenchymal stem cells. Journal of cellular biochemistry 106:232-246.

14. Cho, E.S., Kim, M.K., Son, Y.O., Lee, K.S., Park, S.M., and Lee, J.C. 2012. The effects of rosiglitazone on osteoblastic differentiation, osteoclast formation and bone resorption. Molecules and cells 33:173-181.

15. Remen, K.M., Henning, P., Lerner, U.H., Gustafsson, J.A., and Andersson, G. 2011. Activation of liver $\mathrm{X}$ receptor (LXR) inhibits receptor activator of nuclear factor kappaB ligand (RANKL)-induced osteoclast differentiation in an LXRbeta-dependent mechanism. The Journal of biological chemistry 286:33084-33094.

16. Kleyer, A., Scholtysek, C., Bottesch, E., Hillienhof, U., Beyer, C., Distler, J.H., Tuckermann, J.P., Schett, G., and Kronke, G. 2012. Liver X receptors orchestrate osteoblast/osteoclast crosstalk and counteract pathologic bone loss. Journal of bone and mineral research : the official journal of the American Society for Bone and Mineral Research 27:2442-2451.

17. Prawitt, J., Beil, F.T., Marshall, R.P., Bartelt, A., Ruether, W., Heeren, J., Amling, M., Staels, B., and Niemeier, A. Short-term activation of liver $X$ receptors inhibits osteoblasts but long-term activation does not have an impact on murine bone in vivo. Bone 48:339-346.

18. Id Boufker, H., Lagneaux, L., Fayyad-Kazan, H., Badran, B., Najar, M., Wiedig, M., Ghanem, G., Laurent, G., Body, J.J., and Journe, F. 2011. Role of farnesoid X receptor (FXR) in the process of differentiation of bone marrow stromal cells into osteoblasts. Bone 49:1219-1231.

19. Cho, S.W., An, J.H., Park, H., Yang, J.Y., Choi, H.J., Kim, S.W., Park, Y.J., Kim, S.Y., Yim, M., Baek, W.Y., et al. 2013. Positive regulation of osteogenesis by bile acid through FXR. Journal of bone and mineral research : the official journal of the American Society for Bone and Mineral Research 28:2109-2121.

20. Tabb, M.M., Sun, A., Zhou, C., Grun, F., Errandi, J., Romero, K., Pham, H., Inoue, S., Mallick, S., Lin, M., et al. 2003. Vitamin K2 regulation of bone homeostasis is mediated by the steroid and xenobiotic receptor SXR. The Journal of biological chemistry 278:43919-43927. 


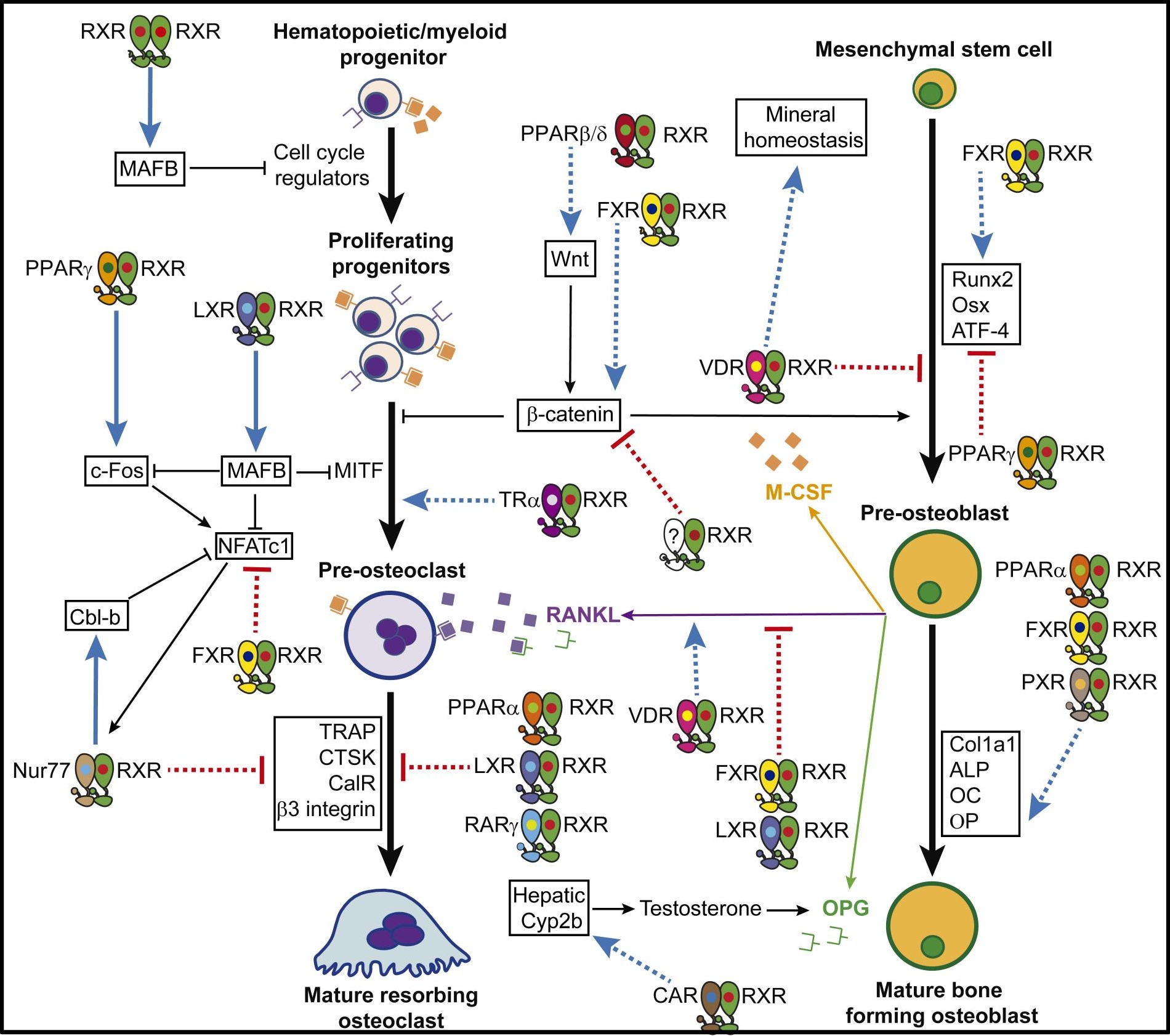

